\title{
HI(E)STÓRIA DE UMA ENTREVISTA
}

\section{Patricia Tenório}

Tudo começou em Fevereiro de 2013. Havia recebido o convite da Profa. Dra ${ }^{a}$. Maria do Carmo Nino para escrever um texto sobre Literatura e Artes Visuais, e me lembrei de um livro que, há muito tempo, uma professora me ofereceu e provocou:

- Escreva sobre o olhar dessas pessoas, Patricia.

Esse livro era Portraits, do fotógrafo americano Steve McCurry. O fato de praticamente não possuir palavras me inquietou e fez aceitar o convite das duas professoras: a primeira prefigurando o que seria preenchido pela segunda.

Aproveitando outro convite da poetisa Flavia Cosma para participar do VII Festival Internacional de Escritores e Artistas de Val-David, no Canadá, entrei em contato, em Fevereiro ainda, com Steve McCurry através de seu blog. Perguntava da possibilidade de uma entrevista para o nosso livro quando da minha ida ao Canadá, com uma passagem por Nova York, entrevista que pensei ampliar para os demais participantes.

Fui muito bem recebida pelos assistentes de McCurry, que me informaram que ele estaria viajando no período da minha ida ao Canadá, mas que aceitava realizar a entrevista.

Foi uma imensa alegria para todos. Pudemos pôr em prática a teoria abordada nos ensaios e/ou outros questionamentos afins que envolvem esse diálogo entre as artes. Após reunirmos as perguntas de cada participante enviamos aos assessores de Steve McCurry para repassarem para ele e nos responder.

Junho. Julho. Agosto de 2013. Iniciou-se uma troca de e-mails com os assessores, e até mesmo telefonemas para sabermos a situação da entrevista. Os desencontros eram sequenciais, as viagens de McCurry constantes, e todos aguardávamos ansiosos por um posicionamento e resposta do fotógrafo.

20 de Dezembro de 2013. Viajando com minha família para Nova York resolvi tentar mais uma vez um retorno quanto à nossa entrevista. Não acreditava muito em uma resposta. Afinal, desde o convite e aceitação de McCurry, em Fevereiro, haviam transcorrido 10 meses.

23 de Dezembro de 2013. Antevéspera de Natal. Ao abrir a caixa de e-mails em um hotel em Nova York, na mesma cidade do escritório da Magnum, agência a qual Steve McCurry é associado, havia a resposta de sua assistente contendo a entrevista. Pulei, cantei, vibrei a boa nova! Como se em algum lugar daquela "cidade que nunca dorme" eu pudesse ver Steve McCurry com um gorro vermelho nos dizendo "Ho-ho-ho". E nós, a maioria dos participantes deste dossiê, do outro lado da América, lhe dizendo: Feliz Natal, Steve! 